\title{
Author's Response to the Letter to the Editor Regarding: Practical Treatment of Lewy Body Disease in the Clinic: Patient and Physician Perspectives
}

Elisabet Londos

Received: February 20, 2018 / Published online: April 27, 2018

(C) The Author(s) 2018

Brzezicki and Kobetić's [1] comments on the case of a patient with Lewy Body Dementia [2] are important. Diagnostic precision and consideration of possible differential diagnoses should, of course, be the foundation of successful treatment.

In dementia with Lewy bodies (DLB), we are bound to rely on the clinical criteria [3] after having determined whether the state is a neurocognitive disorder of minor or major type according to diagnostic and statistical manual of mental disorders (DSM5) [4]. In the actual patient's case, he could not and still cannot manage all his activities of daily living (ADL) needs during his episodes of reduced wakefulness and attention, leading to affected cognition. This means that the level of the disorder is major.

When the patient first came to the Memory Clinic, Alzheimer's disease (AD) was suspected,

Author's Response to Letter to the Editor by Brzezicki, M., Neurol Ther (2018) https://doi.org/10.1007/s40120018-0098-8, regarding the article by Londos, E., Neurol Ther (2017) https://doi.org/10.1007/s40120-017-0090-8.

Enhanced digital content To view enhanced digital content for this article, go to https://doi.org/10.6084/ m9.figshare.6097541.

E. Londos $(\bowtie)$

Lund University, Skane University Hospital, Institute of Clinical Sciences Malmö, Clinical

Memory Research Unit, Malmö, Sweden

e-mail: elisabet.londos@skane.se probably because his main complaint was forgetfulness. However, the patient also described difficulties with mathematics (he had previously been very good at this) and episodic confusion. The CSF investigation showed a total tau of $510 \mathrm{ng} / \mathrm{ml}(<400)$, beta-amyloid $340 \mathrm{ng} /$ $\mathrm{ml}(>550)$, P-tau $72 \mathrm{ng} / \mathrm{ml}(<80)$ and neurofilament (NFL) $1120 \mathrm{ng} / \mathrm{ml}(<1850)$ (with reference values in parentheses) interpreted as a slightly increased T-tau and decreased betaamyloid level. However, the P-tau level was not increased, which would have been a stronger indication of AD. The CT showed no medial temporal atrophy but moderate white matter changes. Mini mental state examination (MMSE) was initially 27 and is still, almost 10 years later, 28. Summarizing these results, I find it not plausible that the diagnosis is only AD with normal NFL and the subcortical parts probably not gravely affected. Despite treatment, the $\mathrm{AD}$ component seems to be small since we cannot catch it in MMSE. It is however very likely that there is a small $\mathrm{AD}$ component since this is more common compared with the opposite in DLB. Differentiation from Parkinson's disease dementia (PDD) only depends on the order in which the symptoms appear $[3,5]$. Since parkinsonism was the last of the DLB core criteria to appear clinically in the patient, this by definition rules out both Parkinson's disease and PDD. Vascular dementia should also be considered. The patient had an episode several 
years before he came to the Memory Clinic in which a stroke was suspected, and in an early CT scan a small infarct in the basal ganglia was noted. The symptom at that time was evaluated as delirium. However, the description today by the patient's wife could lead to suspicion of a vascular event. The fact that parkinsonism appeared several years after that and is still very mild does not make this infarct plausible as the cause of the whole clinical picture but could, as in many older persons, be an additive factor.

I absolutely agree that the treatment we have today can be used in dementias of different origins with positive effects, considering that it is the location rather than the type of pathology that affects the neurotransmitter status in the brain. For example, whether the nucleus basalis of Meynert is affected by $\alpha$-synuclein, plaques or tangles, it probably leads to lowering of the acetyl choline levels. We really do lack suitable blood and CSF markers to measure the neurotransmitters we hope to affect with our current treatment! As diagnostics work today, we strive to reveal the actual pathology and underlying disease for which we do not have any treatment to offer!

The DLB criteria from 1996 [6] were characterized by high specificity but low sensitivity [7], which contributes to under-recognition. To increase sensitivity, the criteria were revised in 2005 and 2017 [3, 8]. Also, from my own clinical perspective from my experience with DLB patients investigated with neuropathology, I agree that the criteria are specific. With more core criteria, a higher degree of $\alpha$-synuclein was found in a study by Fujishiro et al. [9]. The actual patient had suspected REM sleep behavior disorder with "wild nightmares" and acting out; sometimes the figures from the dreams also appeared in daytime (visual hallucinations?), with fluctuating cognition due to variations in wakefulness and alertness as the most prominent symptom and eventually mild parkinsonism. This meets four out of four core criteria. Further supporting the DLB diagnosis in the patient is a cognitive profile with visuospatial and mathematical difficulties rather than actual episodic memory problems, presence of supporting criteria such as orthostatic blood pressure and a depressive propensity because of good insight and the patient's feeling of being a burden to his wife. Also the prompt response to rivastigmine and memantine is clinically more common in DLB compared with $\mathrm{AD}$ and vascular dementia. However, considering the patient's age, mixed pathologies are plausible. In my opinion, an LB pathology is dominant. We can never know for sure, but can just be happy knowing that that the possibility of improvement in these patients exists.

\section{ACKNOWLEDGEMENTS}

This response is based on a medical commentary illustrated by a case.

Funding. No funding or sponsorship was received for this study or publication of this comment.

Authorship. All named authors meet the International Committee of Medical Journal Editors (ICMJE) criteria for authorship for this article, take responsibility for the integrity of the work as a whole, and have given their approval for this version to be published.

Disclosures. Elisabet Londos has nothing to disclose.

Compliance with Ethics Guidelines. This article is based on previously conducted studies and does not contain any studies with human participants or animals performed by any of the authors.

Open Access. This article is distributed under the terms of the Creative Commons Attribution-NonCommercial 4.0 International License (http://creativecommons.org/licenses/ by-nc/4.0/), which permits any noncommercial use, distribution, and reproduction in any medium, provided you give appropriate credit to the original author(s) and the source, provide a link to the Creative Commons license, and indicate if changes were made. 


\section{REFERENCES}

1. Brzezicki MA, Kobetić MD. Letter to the editor regarding: practical treatment of Lewy body disease in the clinic: patient and physician perspectives. Neurol Ther. 2018. https://doi.org/10.1007/s40120018-0098-8.

2. Londos E. Practical treatment of Lewy body disease in the clinic: patient and physician perspectives. Neurol Ther. 2017. https://doi.org/10.1007/s40120-0170090-8.

3. McKeith IG, Boeve BF, Dickson DW, Halliday G, Taylor JP, Weintraub D, Aarsland D, Galvin J, Attems J, Ballard CG, Bayston A, Beach TG, Blanc F, Bohnen $\mathrm{N}$, Bonanni L, Bras J, Brundin P, Burn D, Chen-Plotkin A, Duda JE, El-Agnaf O, Feldman H, Ferman TJ, Ffytche D, Fujishiro $H$, Galasko D, Goldman JG, Gomperts SN, Graff-Radford NR, Honig LS, Iranzo A, Kantarci K, Kaufer D, Kukull W, Lee VMY, Leverenz JB, Lewis S, Lippa C, Lunde A, Masellis M, Masliah E, McLean P, Mollenhauer B, Montine TJ, Moreno E, Mori E, Murray M, O'Brien JT, Orimo S, Postuma RB, Ramaswamy S, Ross OA, Salmon DP, Singleton A, Taylor A, Thomas A, Tiraboschi P, Toledo JB, Trojanowski JQ, Tsuang D, Walker Z, Yamada M, Kosaka K. Diagnosis and management of dementia with Lewy bodies: fourth consensus report of the DLB consortium. Neurology. 2017;89(1):88-100.

4. American Psychiatric Association. Diagnostic and statistical manual of mental disorders. 5th ed. Arlington: American Psychiatric Association; 2013.

5. Emre M, Aarsland D, Brown R, Burn DJ, Duyckaerts C, Mizuno Y, Broe GA, Cummings J, Dickson DW, Gauthier S, Goldman J, Goetz C, Korczyn A, Lees A, Levy R, Litvan I, McKeith I, Olanow W, Poewe W, Quinn N, Sampaio C, Tolosa E, Dubois B. Clinical diagnostic criteria for dementia associated with
Parkinson's disease. Mov Disord. 2007;22(12):1689-707.

6. McKeith IG, Galasko D, Kosaka K, Perry EK, Dickson DW, Hansen LA, Salmon DP, Lowe J, Mirra SS, Byrne EJ, Lennox G, Quinn NP, Edwardson JA, Ince PG, Bergeron C, Burns A, Miller BL, Lovestone S, Collerton D, Jansen EN, Ballard C, de Vos RA, Wilcock GK, Jellinger KA, Perry RH. Consensus guidelines for the clinical and pathologic diagnosis of dementia with Lewy bodies (DLB): report of the consortium on DLB international workshop. Neurology. 1996;47(5):1113-24.

7. Rizzo G, Arcuti S, Copetti M, Alessandria M, Savica R, Fontana A, Liguori R, Logroscino G. Accuracy of clinical diagnosis of dementia with Lewy bodies: a systematic review and meta-analysis. J Neurol Neurosurg Psychiatry. 2018;89:358-66.

8. McKeith IG, Dickson DW, Lowe J, Emre M, O'Brien JT, Feldman H, Cummings J, Duda JE, Lippa C, Perry EK, Aarsland D, Arai H, Ballard CG, Boeve B, Burn DJ, Costa D, Del Ser T, Dubois B, Galasko D, Gauthier S, Goetz CG, Gomez-Tortosa E, Halliday G, Hansen LA, Hardy J, Iwatsubo T, Kalaria RN, Kaufer D, Kenny RA, Korczyn A, Kosaka K, Lee VM, Lees A, Litvan I, Londos E, Lopez OL, Minoshima S, Mizuno Y, Molina JA, Mukaetova-Ladinska EB, Pasquier F, Perry RH, Schulz JB, Trojanowski JQ, Yamada M, Consortium on DLB. Diagnosis and management of dementia with Lewy bodies: third report of the DLB consortium. Neurology. $2005 ; 65(12): 1863-72$.

9. Fujishiro H, Ferman TJ, Boeve BF, Smith GE, GraffRadford NR, Uitti RJ, Wszolek ZK, Knopman DS, Petersen RC, Parisi JE, Dickson DW. Validation of the neuropathologic criteria of the third consortium for dementia with Lewy bodies for prospectively diagnosed cases. J Neuropathol Exp Neurol. 2008;67(7):649-56. 